\title{
TERMINOLOGIA DOTYCZACA POKORY I PYCHY W PISMACH GRECKICH OJCÓW KOŚCIOLA IV WIEKU
}

Charakterystyczną cechą literatury moralno-ascetycznej okresu patrystycznego było wyraźne akcentowanie pokory jako istotnej dyspozycji duchowej, a zarazem ważnej cnoty moralnej. Badacze myśli patrystycznej, pisząc o pokorze, najczęściej koncentrują się na doktrynie św. Augustyna, która w rozwoju wczesnochrześcijańskich poglądów dotyczących tej cnoty stanowi punkt szczytowy ${ }^{1}$. Biskup Hippony wysuwał pokorę na pozycję fundamentu wszystkich cnót i podstawę dla porządku miłości (ordo amoris). Należy jednak pamiętać, że ten sposób myślenia charakterystyczny był już dla wczesnego monastycyzmu i ukształtował się w dużym stopniu na Wschodzie. W niniejszym artykule pragnę poddać analizie terminologię dotyczącą pokory, występującą w pismach greckich Ojców Kościoła tworzących w IV stuleciu, czyli w „,złotym wieku patrystyki”, bezpośrednio poprzedzających działalność Augustyna. Są to przede wszystkim dzieła trzech Ojców Kapadockich - św. Bazylego Wielkiego, św. Grzegorza z Nazjanzu i św. Grzegorza z Nyssy - czołowych teologów i ascetów Kościoła Wschodniego w IV wieku, związanych ze sobą więzami krwi lub przyjaźni oraz wspólnych poglądów. Stosowane przez nich słownictwo zostanie porównane z terminologią współczesnego im wybitnego

\footnotetext{
${ }^{*}$ Ks. prof. dr hab. Mariusz Szram - kierownik Katedry Teologii i Literatury Patrystycznej w Instytucie Historii Kościoła i Patrologii na Wydziale Teologii Katolickiego Uniwersytetu Lubelskiego Jana Pawła II; e-mail: m.szram@wp.pl.

${ }^{1}$ Por. O. Schaffner, Christliche Demut. Des hl. Augustinus Lehre von der Humilitas, Würzburg 1959; A. Eckmann, Nauka świętego Augustyna o pokorze jako podstawie ascezy chrześcijańskiej, w: Wczesnochrześcijańska asceza. Zagadnienia wybrane, red. F. Drączkowski - J. Pałucki, Lublin 1993, 83-97; N. Baumann, De fundamento prius cogita humilitatis: Die Demut als Grundlage aller Tugenden bei Augustinus, Roma 2008. W odniesieniu do innych pisarzy kościelnych epoki patrystycznej temat pokory nie był podejmowany w szerszym wymiarze przez współczesnych patrologów. Na gruncie teologii polskiej należy zwrócić uwagę na dwa przekrojowe, syntetyczne opracowania, napisane nota bene przez moralistę ks. Stanisława Witka, oraz na opublikowany przed kilkoma laty artykuł piszącego te słowa, por. S. Witek, Koncepcje pokory $w$ patrystyce Wschodu, AnCra 2 (1970) 257-278; tenże, Interpretacja pokory w patrystyce zachodniej, RTK 17 (1970) z. 3,

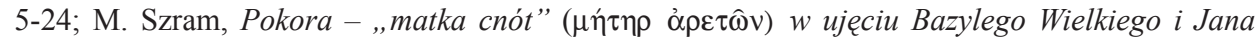
Chryzostoma, RT 51 (2004) z. 4, 43-64.
} 
kaznodziei św. Jana Chryzostoma, któremu temat pokory jako „matki cnót” był również niezwykle bliski².

Pokora była omawiana w okresie patrystycznym w powiązaniu z wadą pychy. Bardzo często można natrafić w spuściźnie Ojców Kościoła na homilie i traktaty poświęcone wadom, w których znajduje się wręcz kopalnia informacji o przeciwstawnych im cnotach ${ }^{3}$. W moich analizach zwracam więc uwagę także na terminologię dotyczącą pychy jako korzenia wszelkich grzechów, na którą lekarstwem jest pokora.

W pismach Ojców Kapadockich i Jana Chryzostoma na określenie pokory pojawiały się tradycyjne terminy: $\tau \alpha \pi \varepsilon i ́ v \omega \sigma ı \varsigma ~ l u b ~ \tau \alpha \pi \varepsilon ı v o ́ \tau \eta \varsigma-$ wywodzące się ze starożytnej filozofii ${ }^{4}$, ale występujące również w Septuagincie i pismach

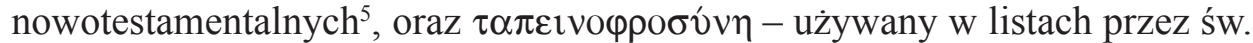
Pawła i św. Piotra ${ }^{6}$. Należy pamiętać, że antyczna myśl grecka nie znała cnoty pokory, dlatego nie używała ostatniego z powyższych terminów. Natomiast dwa pierwsze miały u starożytnych zazwyczaj sens pejoratywny i oznaczały małość, słabość, nędzę ${ }^{7}$. Jedyny zachowany tekst, w którym słowo $\tau \alpha \pi \varepsilon \imath$ vó nabiera pozytywnego znaczenia i który był cytowany później w wykładzie o pokorze przez autorów chrześcijańskich ${ }^{8}$ (chociaż nie przez teologów będących bohaterami niniejszego artykułu), znajduje się w Prawach Platona9

${ }^{2}$ Przy ustalaniu znaczenia terminów omawianych w niniejszym artykule posługiwałem się pomocniczo następującymi słownikami: H.G. Liddell - R. Scott, A Greek-English Lexicon, Oxford 1940; Stownik grecko-polski, I-IV, red. Z. Abramowiczówna, Warszawa 1958-1965; R. Popowski, Wielki słownik grecko-polski Nowego Testamentu, Warszawa 1995; G.W.H. Lampe, A Patristic Greek Lexicon, Oxford 1978.

${ }^{3}$ Przykładem mogą być współczesne Kapadocczykom pisma Ewagriusza z Pontu, a zwłaszcza dwa traktaty: Practicus, ed. A. Guillaumont - C. Guillaumont, SCh 170-171, Paris 1971; De octo spiritibus malitiae, PG 79, 1145-1164. Zwrócił na tę prawidłowość uwagę L. Misiarczyk w książce Osiem logismoi w pismach Ewagriusza z Pontu, Kraków 2007, 17-26.

${ }^{4}$ Por. Plato, Leges IV 716a 4, ed. R.G. Bury, I, The Loeb Classical Library, London - Cambridge Mass. 1961, 294; Aristoteles, Rhetorica II 6, 1384a 4, ed. M. Dufour, II, Paris 1938, 77.

${ }^{5}$ Por. So 3, 12; Ps 138, 6; Syr 3, 18-19; Mt 11, 29; Łk 1, 48; zob. P. Adnès, Humilité, DSp VII

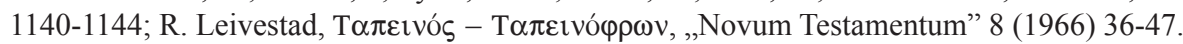

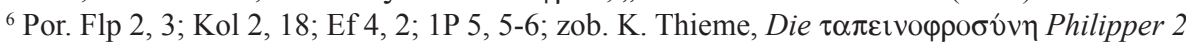
und Römer 12, ZNW 8 (1907) 9-33; P. Adnès, Humilité, kol. 1148-1150.

${ }^{7}$ Por. Aristoteles, Rhetorica II 12, 1389b 25-27, ed. Dufour, II, s. 93; Plutarchus, De tranquillitate animi 17e-f, ed. G.N. Bernardakis, w: Plutarchus Chaeronensis, Moralia, III, Bibliotheca Scriptorum Graecorum et Romanorum Teubneriana, Lipsiae 1891, 235-236; Seneca, De constantia sapientis 10, 2-3, ed. R. Waltz, w: Sénèque, Dialogues, IV, Paris 1927, 48-49.

${ }^{8}$ Por. Clemens Alexandrinus, Stromata II 22, 132-133, ed. C. Mondésert - P.Th. Camelot, SCh 38, Paris 1954, 134; Origenes, Contra Celsum 6, 15, ed. M. Borret, SCh 147, Paris 1969, 214-216.

${ }^{9}$ Por. Plato, Leges IV 715e-716b, ed. Bury, s. 292-294; thum. M. Maykowska: Platon, Prawa, Warszawa 1997, 147-148: „Mężowie [...] bóg, który, jak głosi prastare orędzie, początek, koniec i środek dzierży wszelkiego istnienia, prostą zmierza drogą w swym zgodnym z przyrodzonym porządkiem rzeczy wieczystym obrocie. Towarzyszy mu zawsze Sprawiedliwość, gardzicieli prawa bożego mścicielka. Trzyma się jej ten, kto chce wieść szczęsny żywot, i podąża w jej ślady, maluczki 
Termin $\tau \alpha \pi \varepsilon \imath$ vós oznacza tam postawę umiarkowania, które przeciwstawia się pysze (úßpıৎ) i zbliża człowieka do Boga.

1. W pismach Bazylego Wielkiego. W pismach Bazylego formy z rdzeniem $\tau \alpha \pi \varepsilon \imath \nu$-, szczególnie przymiotnik $\tau \alpha \pi \varepsilon \iota v o ́ \varsigma$, niezależnie od kontekstu wyrażają stan znajdowania się niżej od czegoś lub kogoś innego. Omawiając konstrukcję człowieka Kapadocczyk zwraca uwagę, że głowa jest umieszczona na szyi, aby mogła wystawać nad ramionami i nie wydawała się położona

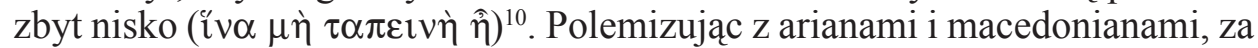
pomocą tego właśnie przymiotnika określa błędne stawianie Syna i Ducha niżej od Ojca ${ }^{11}$. Wykładając ortodoksyjną teologię używa go, gdy mówi o wcieleniu Syna jako zejściu do stanu uniżenia i słabości właściwego człowiekowi

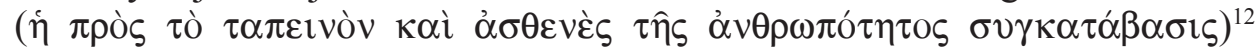

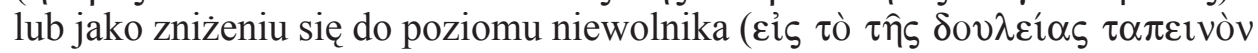

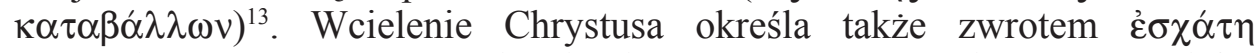
$\tau \alpha \pi \varepsilon \imath v o ́ \tau \eta \varsigma$ - „ostateczne uniżenie się”, co można rozumieć zarówno jako uniżenie w czasach ostatecznych, jak i uniżenie skrajne, do granic możliwości ${ }^{14}$. Często odwołuje się do zawierającego przymiotnik $\tau \alpha \pi \varepsilon \imath v o ́ \varsigma$ ewange-

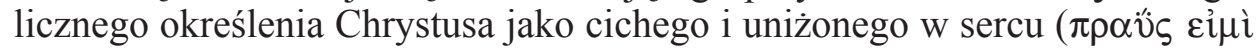

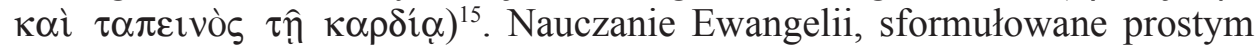

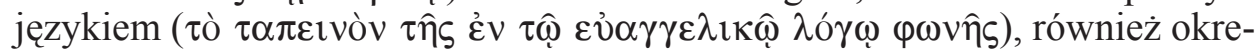
śla tym samym przymiotnikiem, wyrażającym w tym wypadku niższy rodzaj wymowy, przeciwny stylowi wzniosłemu i ozdobnemu ${ }^{16}$.

Niekiedy Kapadocczyk nadaje przymiotnikowi $\tau \alpha \pi \varepsilon \imath$ vó wyraźne znaczenie negatywne. Za jego pomocą wyraża zawiniony stan nędzy, będący następ-

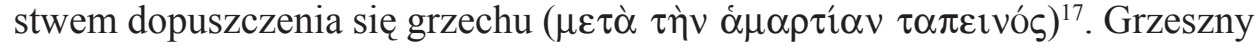
czyn - jak mówi Bazyli - sprawia, że człowiek musi po nim czuć się skru-

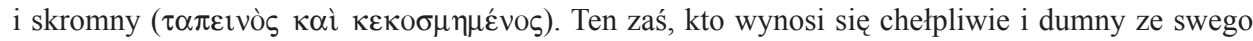
bogactwa, zaszczytów czy piękności cielesnej, młodzieńczą butą i głupotą pali się w duszy i pychą

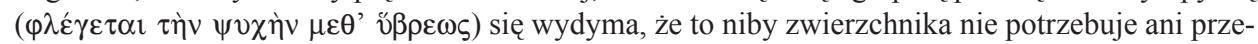
wodnika, lecz sam zdolny jest przewodzić innymi, odrzucony zostaje przez boga i pozostawiony samemu sobie".

${ }^{10}$ Por. Basilius Caesariensis, De origine hominis 2, 16, ed. A. Smets - M. van Esbroeck, SCh 160, Paris 1970, 270.

${ }^{11}$ Por. tenże, De Spiritu Sancto 6, 15, ed. B. Pruche, SCh 17bis, Paris 1968, 290-296.

${ }^{12}$ Por. tenże, Homiliae super Ps. 44, 5, PG 29, 400B.

${ }^{13}$ Por. tenże, Adversus Eunomium 2, 31, ed. B. Sesboüé - G.M. de Durand - L. Doutreleau, II, SCh 305, Paris 1983, 130.

${ }^{14}$ Por. tenże, De humilitate hom. 6, PG 31, 536B-C.

${ }^{15}$ Por. tamże 7, PG 31, 540B; tenże, Homiliae super Ps. 33, 2, PG 29, 356C; tenże, Asceticon magnum (Regulae brevius tractatae) 197, PG 31, 1213B; tenże, Regulae morales 34, 1, PG 31, 753D; tenże, De baptismo 11, PG 31, 1621B.

${ }^{16}$ Por. tenże, Homiliae super Ps. 44, 10, PG 29, 409A.

${ }^{17}$ Por. tamże 32, 3, PG 29, 332A; tenże, Enarratio in prophetam Isaiam (dubium), PG 30, 393B. 


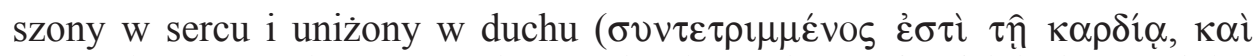
$\tau \alpha \pi \varepsilon \imath$ òs $\tau \hat{\omega} \pi v \varepsilon \hat{\mu} \mu \alpha \tau \imath$ ), ponieważ nic nie poniża go bardziej niż popełnio-

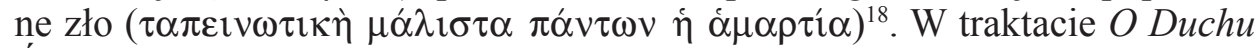
Świętym autor posługuje się terminem $\tau \alpha \pi \varepsilon \imath v o ́ \varsigma$ na określenie rozumowania

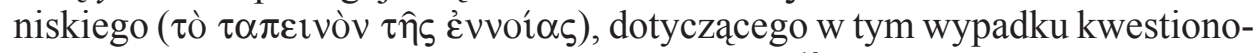
wania wiecznej współdoskonałości Syna z Ojcem ${ }^{19}$. W Homiliach do Psalmów przywołuje wspomniany przymiotnik, gdy stwierdza, że ludzie sprawiedliwi

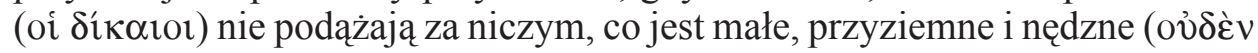

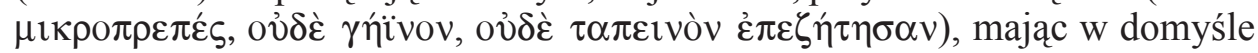
porównanie $\mathrm{z}$ wzniosłymi sprawami związanymi z Bogiem ${ }^{20}$. W liście do senatu Tyany, stolicy jednej z prowincji Kapadocji, określa nim tchórzliwość

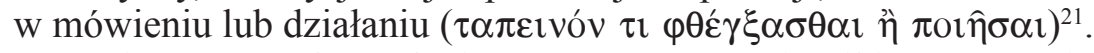

Uniżony sposób myślenia, wyrażony przymiotnikiem $\tau \alpha \pi \varepsilon \imath$ vós, nie musi jednak mieć zabarwienia pejoratywnego, co znajduje odzwierciedlenie w jednym z listów, gdzie charakteryzując człowieka zintegrowanego wewnętrznie

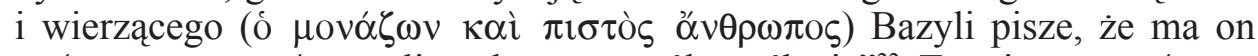

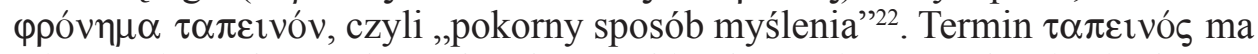
więc w pismach Bazylego charakter ambiwalentny i może odnosić się do rzeczywistości nagannej lub zasługującej na pochwałę.

Mając na myśli godny naśladowania stan uniżenia Kapadocczyk traktuje przymiotnik $\tau \alpha \pi \varepsilon \imath$ vó i pokrewny mu rzeczownik $\tau \alpha \pi \varepsilon i ́ v \omega \sigma ı \varsigma$ jako zbliżone znaczeniowo do terminu $\tau \alpha \pi \varepsilon \iota v o \varphi \rho o \sigma u ́ v \eta^{23}$. Ten ostatni rzeczownik występuje wówczas, gdy chodzi o cnotę pokory i to on został użyty w tytule homilii 20 .,

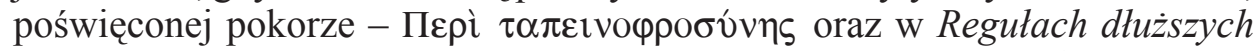
i Regułach krótszych, gdy Bazyli usiłował zdefiniować tę cnotę ${ }^{24}$. Natomiast pierwsze dwa terminy w pozytywnym znaczeniu bywają zazwyczaj odnoszone nie do cnoty pokory, ale do naturalnej postawy uniżenia, wrodzonej każdemu człowiekowi. W wypowiedzi Kapadocczyka nawiązującej do proroka Iza-

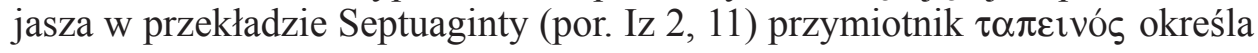

\footnotetext{
18 Por. tenże, Homiliae super Ps. 33, 12, PG 29, 380C-D.

${ }_{19}$ Por. tenże, De Spiritu Sancto VIII 20, 37, SCh 17bis, 318.

${ }^{20}$ Por. tenże, Homiliae super Ps. 33, 12, PG 29, 380A.

${ }^{21}$ Por. tenże, Epistula 97, PG 32, 493C.

${ }^{22}$ Por. Epistula 43, PG 32, 360C.
}

${ }^{23}$ Tenże, Asceticon magnum (Regulae fusius tractatae) 43, 2, PG 31, 1028C, tłum. J. Naumowicz: Św. Bazyli Wielki, Reguty dłuższe, w: Św. Bazyli, Pisma ascetyczne, II, ŹM 6, Kraków 1995 , 160-161: ,[Ci, którym zostało powierzone kierowanie innymi] [...] pierwsi powinni praktykować

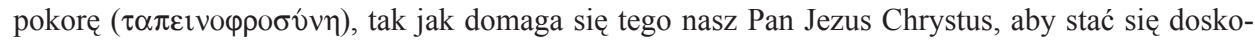
nałymi wzorami tej cnoty, bo On rzekł: «Uczcie się ode Mnie, bo jestem cichy i pokornego serca»

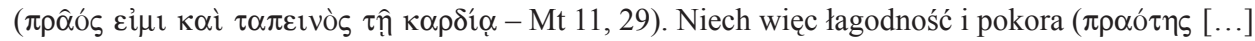

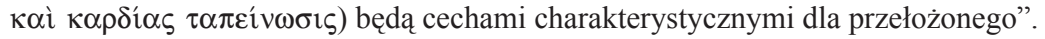

${ }^{24}$ Por. tenże, De humilitate hom. 4, PG 31, 533A-C; tenże, Asceticon magnum (Regulae brevius tractatae) 198, PG 31, 1213; tenże, Asceticon magnum (Regulae fusius tractatae) 22, PG 31, 977. 
niskie, właściwe stworzeniu miejsce, jedyne jakie człowiek może zajmować wobec wzniosłego Boga Stwórcy ${ }^{25}$. W podobny sposób traktowany jest rzeczownik $\tau \alpha \pi \varepsilon i v \omega \sigma ı \varsigma$ w przypisywanych Bazylemu homiliach O pochodzeniu czlowieka, których autorstwo jest jednak wciąż dyskutowane ${ }^{26}$ :

„Bóg ukształtował człowieka jako proch ziemi” (por. Rdz 3, 19). Piękne jest

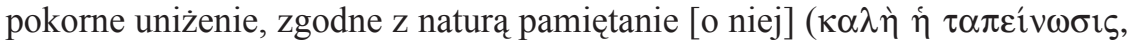

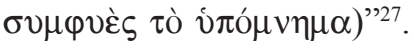

Przekonanie Bazylego, że uformowanie człowieka, stanowiące istotę aktu stwórczego, jest ściśle związane ze stanem niskości i zmusza stworzenie do pokory wobec Stwórcy, znajduje również odzwierciedlenie w zwrocie $\tau$ ò

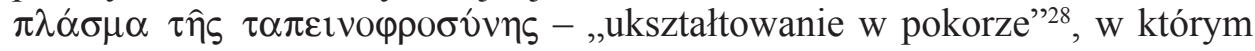
miejsce występującego zwykle $\mathrm{w}$ takim kontekście rzeczownika $\tau \alpha \pi \varepsilon i ́ v \omega \sigma \iota \varsigma$

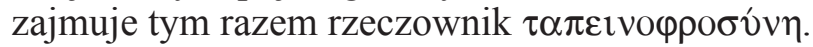

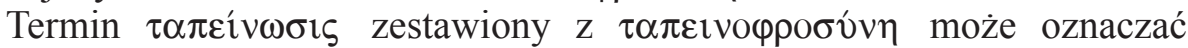
w pismach Kapadocczyka zwykłe uniżenie, skromność, ubóstwo, niekoniecz-

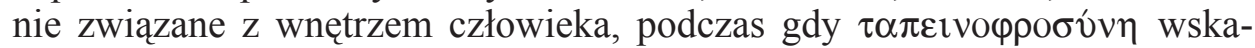
zuje na pokorę jako cnotę moralną. Przykładem może być sformułowanie: „dostatecznym zewnętrznym wyrazem pokory ducha jest skromność przy-

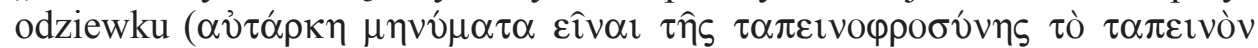

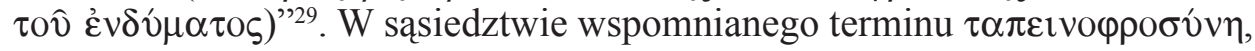
oznaczającego precyzyjnie cnotę pokory, pojawiają się w pismach Kapadoc-

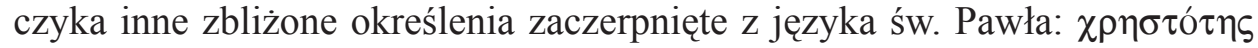
- „dobroć”, „prostota”, $\mu \alpha \kappa \rho о \theta v \mu i \alpha$ - „,ierpliwość”, „wyrozumiałość”, $\pi \rho \alpha o ́ \tau \eta \varsigma$ - „łagodność" "30.

O wiele bogatsza od słownictwa związanego z pokora jest u Bazylego terminologia oznaczająca postawę pychy, przeciwstawiającą się postawie pokory wyrażonej za pomocą słów z rdzeniem $\tau \alpha \pi \varepsilon \imath$-. W tym kontekście

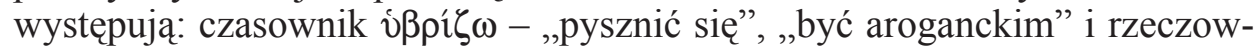
nik ưßpiৎ - ,przekroczenie miary”, „pysznienie się”, a także pokrewny im

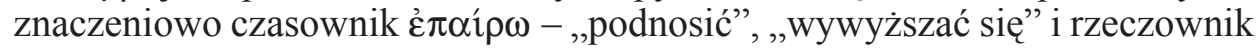

\footnotetext{
${ }^{25}$ Por. tenże, Enarratio in prophetam Isaiam (dubium) 2, 86, PG 30, 257C-D: „Oi yò ỏ ỏ $\theta \alpha \lambda \mu$ oì

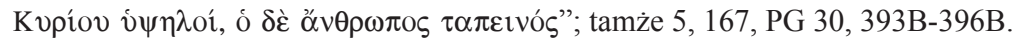

${ }^{26}$ Niektórzy badacze przypisują dziełko raczej Grzegorzowi z Nyssy, inni - autorowi anonimowemu. Por. A. Smets - M. van Esbroeck, Introduction, w: Basile de Césarée, Sur l'origine de l'homme, SCh 160, Paris 1970, 15-26.

${ }^{27}$ Basilius Caesariensis, De origine hominis 2, 13, SCh 160, 262, thum. własne; por. tamże 2, 12, SCh 160, 260, tłum. własne: „Gdy zrobisz cokolwiek - czy to małego czy wielkiego - na ziemi,

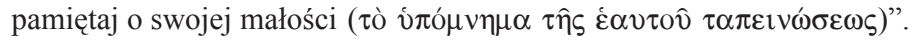

${ }^{28}$ Por. tenże, Epistula 119, PG 32, 537B.

${ }^{29}$ Por. tamże 223, 3, PG 32, 325A.

${ }^{30}$ Por. tenże, Homiliae super Ps. 44, 11, PG 29, 412B; tenże, Regulae morales 69, 2, PG 31, 816B; tenże, De Spiritu Sancto 15, 35, SCh 17bis, 366.
} 


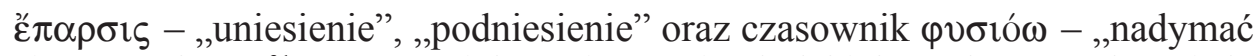
się", „puchnać" potępienia i dzielenia losu z diabłem, mówi Bazyli używając terminów znanych w starożytności, zwłaszcza z Teofrasta i pism stoickich. Są to rzeczowni-

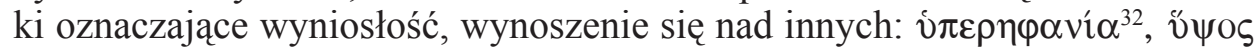
(także użyte łącznie w zwrocie v̋ $\psi \varsigma \varsigma$ vं $\pi \varepsilon \rho \eta \varphi \alpha v i \alpha \varsigma$ - „uniesienie przez pychę-

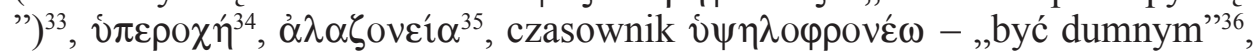

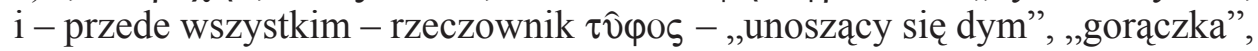
„nadęcie”, ,próżność" ${ }^{37}$, któremu jest przeciwstawiane określenie cnoty po-

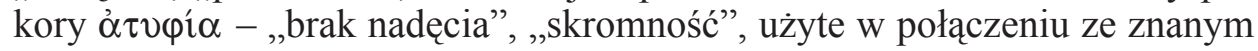
z literatury starożytnej opisem choroby wzdęcia ciała ${ }^{38}$. Synonimem powyższych terminów oznaczających grzeszną wyniosłość jest powtarzany przez Bazylego często w homilii O pokorze rzeczownik $\delta o ́ \xi \alpha-$ - ,chwała”, opatrzony

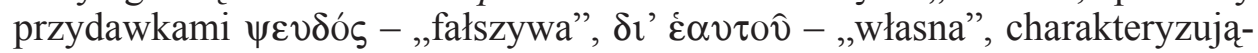
cy pychę szatana i tych, którzy ulegli jego pokusie. Jej przeciwieństwem jest

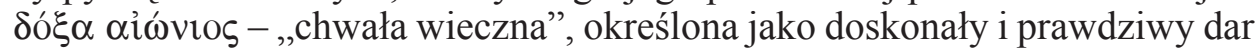

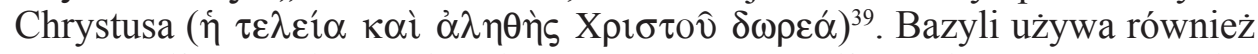

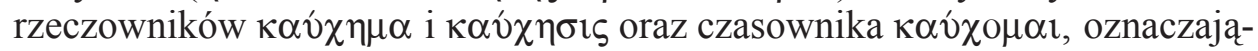
cych zarozumiałość i wyniosłość. Opatrzony przydawkami $\alpha \lambda \eta \theta \dot{\varepsilon} \varsigma$ - „dobry”,

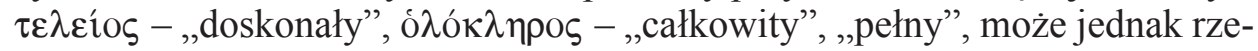

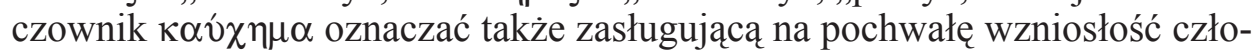
wieka, który chlubi się w Panu, podobnie jak użyte w zbliżonym kontekście

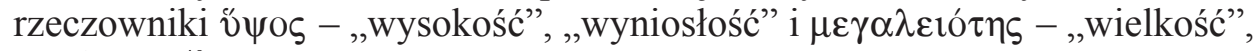
„majestat"

${ }^{31}$ Por. tenże, De origine hominis 2, 12, SCh 160, 262; tamże 1, 19, SCh 160, 216; tenże, De humilitate hom., passim (spec. 1, PG 31, 525).

${ }^{32}$ Por. tenże, De humilitate hom. 1, PG 31, 525C.

${ }^{33}$ Por. tamże 3, PG 31, 532A.

${ }^{34}$ Por. tenże, Asceticon magnum (Regulae brevius tractatae) 35, PG 31, 1105B.

${ }^{35}$ Por. tenże, De humilitate hom. 3, PG 31, 532A.

${ }^{36}$ Tamże 4, PG 31, 532C.

${ }^{37}$ Por. tenże, Adversus Eunomium 1, 13, SCh 299, 218, tłum. własne: „Wydaje się, że py-

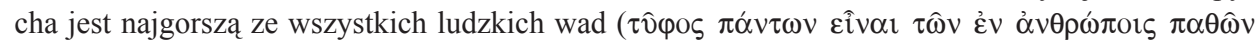
$\chi \alpha \lambda \varepsilon \pi \omega ́ \tau \alpha \tau o v)$. Strąca ona w diabelskie potępienie tych, w których wzrasta".

${ }^{38}$ Bazyli nawiązuje do terminologii stoików. Piętnując wadę pychy określali ją oni wymownym terminem - „dym” ( $\tau \hat{\varphi} \varphi \varsigma_{\text {) }}$, wskazującym zarówno na wynoszenie się, jak i na ulotność i próżność.

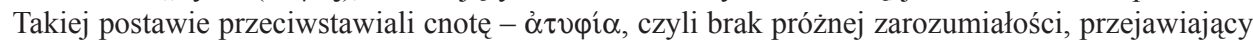
się w przyjmowaniu z obojętnością zarówno złych, jak i dobrych opinii o sobie, por. Diogenes Laertios, Vitae philosophorum VII 1, 117, ed. H.G. Huebnerus, II, Lipsiae 1831, 164, thum. I. Krońska - K. Leśniak - W. Olszewski - B. Kupis: Diogenes Laertios, Żywoty i poglady stynnych filozofów,

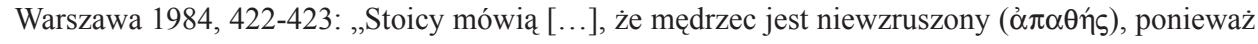

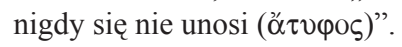

${ }^{39}$ Por. Basilius Caesariensis, De humilitate hom. 6, PG 31, 537A.

${ }^{40}$ Por. tamże 3, PG 31, 529B-C. 
W Regułach krótszych Bazyli próbuje uporządkować bogatą terminologię stosowaną na oznaczenie pychy, definiując i klasyfikując różne odmiany tej wady:

„Pyszny ( $\{\psi \eta \lambda o ́ \varphi \rho \omega v)$ jest ten, kto się wywyższa (í $\psi \hat{\omega} v)$ oraz jest przeko-

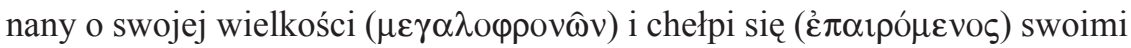
dobrymi uczynkami, jak ów faryzeusz (por. Łk 18, 11), a nie pociaga go to,

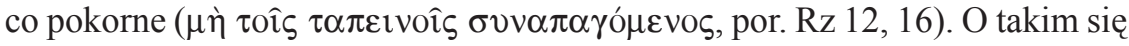
też mówi, że «unosi się pychą» ( $\pi \varepsilon \varphi v \sigma \iota \omega \mu \varepsilon ́ v o \varsigma)$, jak powiedziano w oskarżeniu skierowanym do Koryntian (1Kor 5, 2). Zarozumiały ( $\dot{\alpha} \lambda \alpha \zeta \omega$ v v) to ten, który nie przestrzega rzeczy ustanowionych i nie wypełnia nakazu, aby stosować się do tych samych zasad (por. Flp 3, 16) i do tych samych dążeń (por.

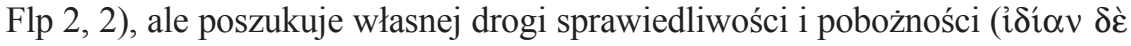

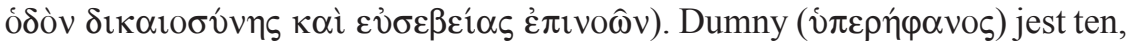

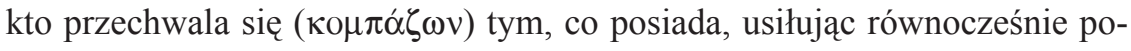

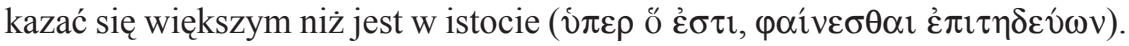

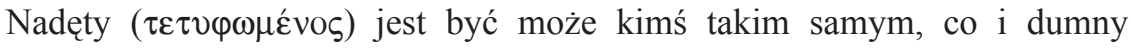
( nadęty ( $\tau \varepsilon \tau \hat{\varphi} \varphi \omega \tau \alpha)$ ), niczego nie pojmuje» $(1 \mathrm{Tm} 6,4){ }^{\prime 41}$.

Ściśle rzecz biorąc przeciwieństwem człowieka pokornego określanego terminem $\tau \alpha \pi \varepsilon \imath$ vó jest - w świetle powyższej wypowiedzi - człowiek pysz-

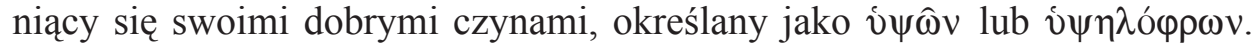
Zarozumialstwo, określane jako $\alpha \lambda \alpha \zeta$ oveí $\alpha$, to postępowanie zgodnie z własną wola, w przekonaniu, że jest ono lepsze niż dostosowanie się do praw ogólnie przyjętych w ludzkiej społeczności. Przesadna duma i nadętość, określane

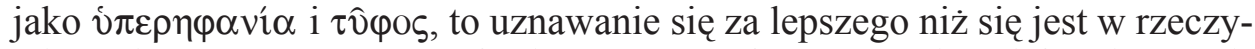
wistości. W przytoczonym tekście postawa pokory rozumiana jako nieprzypisywanie sobie dobrych czynów, ponieważ w rzeczywistości pochodzą one od Boga i są dokonywane dzięki Jego łasce, została określona przymiotnikiem $\tau \alpha \pi \varepsilon \imath$ ós. Inne teksty Bazylego poświadczają jednak, że wszystkie wspomniane postawy, w jakich przejawia się pycha, najczęściej są przeciwstawiane

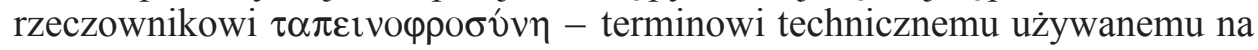
określenie cnoty pokory ${ }^{42}$.

2. W pismach Grzegorza z Nazjanzu. Grzegorz z Nazjanzu - odmiennie niż Bazyli - mówiąc zarówno o wszelkiego rodzaju uniżeniu, jak i o cnocie pokory, używa najczęściej terminu $\tau \alpha \pi \varepsilon i ́ v \omega \sigma ı s$. Przymiotnik ten oznacza -

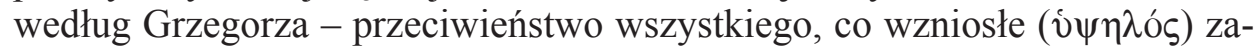
równo w znaczeniu pozytywnym, mającym związek z wielkością Boga, jak

${ }^{41}$ Tenże, Asceticon magnum (Regulae brevius tractatae) 56, PG 31, 1120C-1121A, ŹM 6, 254.

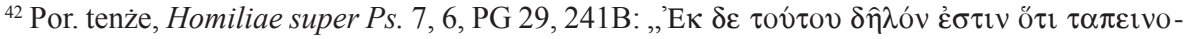

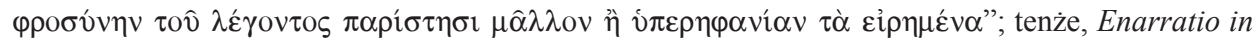
prophetam Isaiam (dubium) 1, 57, PG 30, 221B. 
i negatywnym, odnoszącym się do ludzkiej wyniosłości nieokazującej Bogu należnego szacunku. W zestawieniu z wzniosłością Boga i rzeczywistością duchową ( $\mu \varepsilon \tau \grave{\alpha} \tau o \hat{v} \Theta \varepsilon o \hat{v}, \mu \varepsilon \tau \grave{\alpha} \tau o \hat{v} \pi v \varepsilon v ́ \mu \alpha \tau o \varsigma)$ może on mieć znaczenie pejoratywne, związane z przywiązaniem do świata doczesnego i tego, co cie-

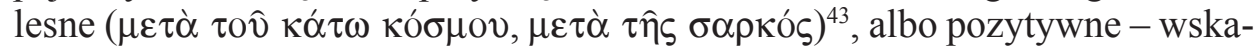
zujące na idealną postawę uniżenia wobec rzeczy wzniosłych, niebiańskich

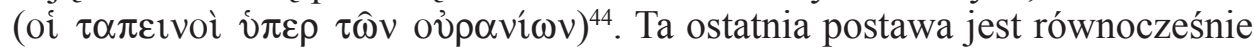
przeciwieństwem wzniosłości negatywnej, prezentowanej przez ludzi okazujących pełną pogardy pychę wobec Boga Stwórcy ${ }^{45}$.

W przekonaniu Grzegorza Teologa termin $\tau \alpha \pi \varepsilon ı$ vó ma związek znaczeniowy z wieloma innymi określeniami odnoszącymi się do tego, co małe

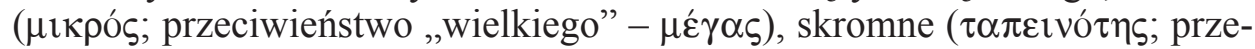

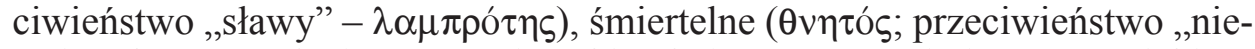

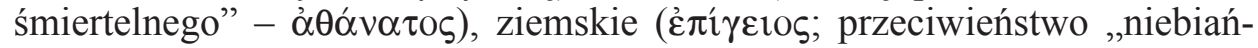

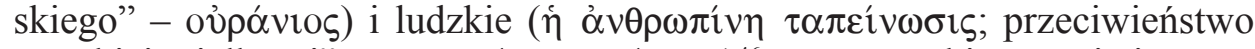

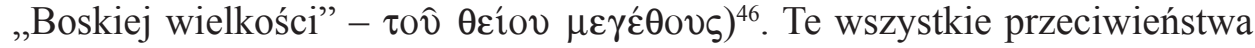
paradoksalnie spotykają się w człowieku, który - zdaniem Grzegorza - jest zawieszony między tym, co ziemskie i niebiańskie:

„Co za dziwna tajemnica otacza mnie [jako człowieka]? Jestem równocze-

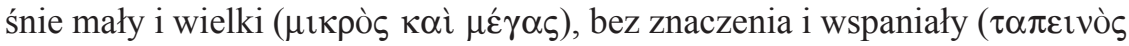

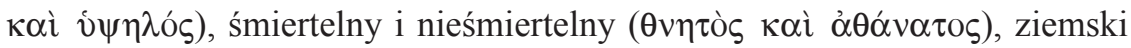

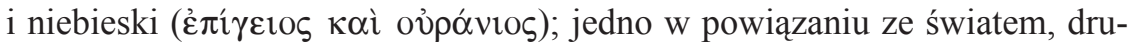

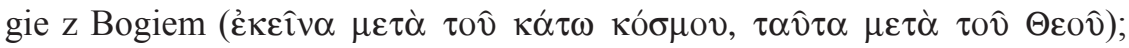

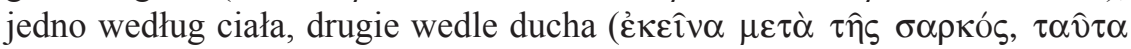
$\mu \varepsilon \tau \grave{\alpha} \tau o \hat{v} \pi v \varepsilon \hat{v} \mu \alpha \tau \circ \varsigma$ ). Muszę być pochowany z Chrystusem (Rz 6, 4; Kol 2, 12), z Chrystusem zmartwychwstać, z Nim współdziedziczyć, stać się synem Boga, samym Bogiem" ${ }^{47}$.

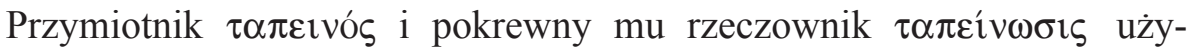
te w pozytywnym kontekście przyjmują u Grzegorza z Nazjanzu znaczenie

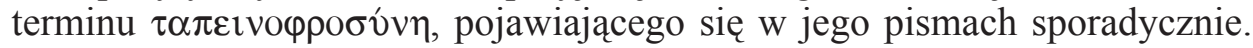

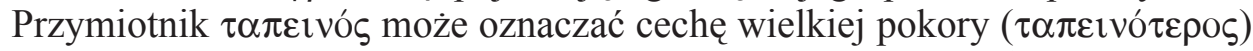
zestawioną z postawą największej doskonałości $(\tau \varepsilon \lambda \varepsilon v \tau \alpha i ́ \varsigma){ }^{48}$. Jest przywoływany w biblijnym określeniu ,pokorni sercem" (por. 2Kor 7, 6) na określe-

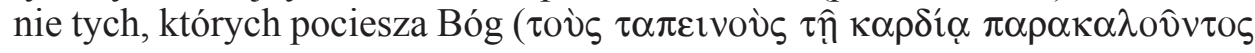

\footnotetext{
${ }^{43}$ Por. Gregorius Nazianzenus, Oratio 2, 76, ed. J. Bernardi, SCh 247, Paris 1978, 188-190.

${ }^{44}$ Por. tamże 6, 2, w. 36-37, ed. M.A. Calvet-Sebasti, SCh 405, Paris 1995, 126.

${ }^{45}$ Por. tamże 3, 2, SCh 247, 244.

${ }^{46}$ Por. tamże 7, 23, SCh 405, 238-240; 2, 5, SCh 247, 94.

${ }^{47}$ Por. tamże 7, 23, SCh 405, 238-240, tłum. zbiorowe: Św. Grzegorz z Nazjanzu, Mowy wybrane, Warszawa 1967, 302.

${ }^{48}$ Por. tamże 2, 49, SCh 247, 154.
} 
$\Theta \varepsilon \circ \widehat{v})^{49}$. Przysłówkiem $\tau \alpha \pi \varepsilon \imath v \hat{\omega} \varsigma$ i czasownikiem $\tau \alpha \pi \varepsilon \iota v o ́ \omega$ określa jednak Grzegorz również - za prorokiem Joelem (Jl 1, 12; por. 1Krl 9, 16) - postawę pokuty, polegającej na przyodzianiu się w wór i upadnięciu w świątyni na

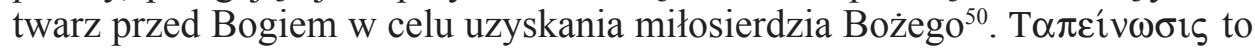
wreszcie także uniżenie zawinione przez grzech, wynikające $\mathrm{z}$ uczynionego zła, ale błogosławione w tym znaczeniu, że może prowadzić do nawrócenia:

\begin{abstract}
„Za upokorzeniem i poniżeniem [idzie] sława wywyższenia. [...] Między grzechem a poprawą [pojawia się] upokorzenie, jako zrodzone z przewinienia, a powodujące poprawę. Albowiem grzech jest ojcem upokorzenia,

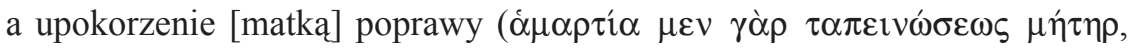

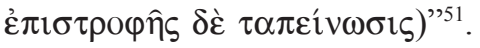

Grzegorz z Nazjanzu nawiązuje do starożytnej terminologii greckiej, od-

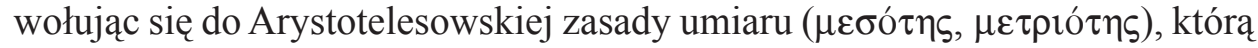
łączy z postawą chrześcijańskiej pokory ${ }^{52}$. Zasada ta, wyrażona $\mathrm{w}$ popularnym gnomie greckim „Nie czyń nic ponad miarę” ( $\mu \eta \delta \grave{\varepsilon} v \not \alpha \gamma \alpha \nu)$, nakazywała we wszystkich czynnościach życiowych zachować ,złoty środek” między nadmiarem i brakiem ${ }^{53}$. Odniesiona do chrześcijańskiej pokory oznaczała unikanie wywyższania się i zajmowanie umiarkowanego, czyli właściwego miejsca przez człowieka jako stworzenia wobec Stwórcy oraz wobec innych podobnych sobie ludzi ${ }^{54}$.

Na określenie przeciwnej pokorze wady pychy Grzegorz używa najczęściej

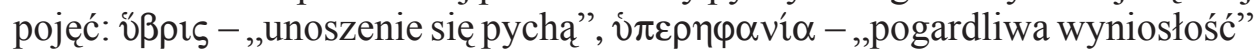

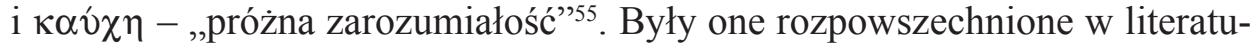
rze starożytnej ${ }^{56}$, występowały także w Septuagincie i księgach nowotestamentalnych (por. Iz 2, 17; 1 Kor 1, 27-29) oraz pismach wczesnochrześcijańskich ${ }^{57}$.

3. W pismach Grzegorza z Nyssy. Trzeci wielki Kapadocczyk, Grzegorz z Nyssy - analogicznie do Grzegorza Teologa - na określenie zarówno

\footnotetext{
${ }^{49}$ Por. tamże 3, 6, SCh 247, 248-250.

${ }^{50}$ Por. tamże 2, 59, SCh 247, 170.

${ }^{51}$ Tamże 4, 32, ed. J. Bernardi, SCh 309, Paris 1983, 130, thum. własne.

${ }^{52}$ Por. tamże, SCh 309, 128-130.

${ }^{53}$ Por. Aristoteles, Rhetorica II 12, 1389b 2-7, ed. Dufour, II, s. 92; tenże, Ethica nicomachea II
} 6, 1107a - 9, 1109b, ed. F. Susemihl - O. Apelt, Bibliotheca Scriptorum Graecorum et Romanorum Teubneriana, Lipsiae 1912, 35-42.

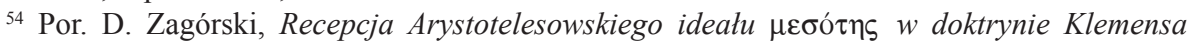
Aleksandryjskiego. Problem definicji, RT 51 (2004) z. 4, 5-42.

${ }^{55}$ Por. Gregorius Nazianzenus, Oratio 4, 32, SCh 309, 128-130; 5, 18, SCh 309, 328.

${ }^{56}$ Por. Solon, Fragmenta 15, 7-8, w: Poetae minores graeci, ed. Th. Gaisford, III, Lipsiae 1823, 140; Plato, Leges IV 715e-716b, ed. Bury, s. 292-294; Theophrastus, Characteres 24, ed. J.D. Edmonds, The Loeb Classical Library, London - Cambridge Mass. 1961, 102-104.

${ }^{57}$ Por. Basilius Caesariensis, De humilitate hom. 1, PG 31, 525C; tenże, Asceticon magnum (Regulae brevius tractatae) 56, PG 31, 1120C-1121A. 
postawy uniżenia, jak i cnoty pokory, posługiwał się przeważnie terminem $\tau \alpha \pi \varepsilon i ́ v \omega \sigma ı \varsigma$. Uniżenie określane tym rzeczownikiem to dla niego - podobnie

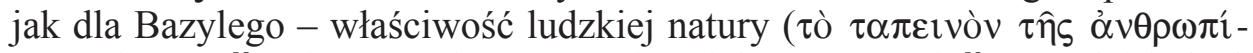

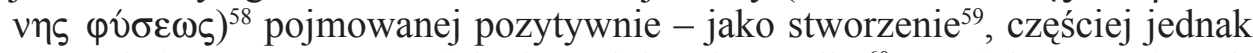
W aspekcie negatywnym - jako byt zdolny do upadku ${ }^{60}$ oraz jako stan niewol-

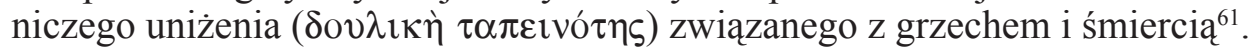

W traktacie De virginitate termin $\tau \alpha \pi \varepsilon i ́ v \omega \sigma ı \varsigma$ pojawia się wyłącznie w znaczeniu negatywnym jako określenie spraw i rzeczy niskich, małowartościowych, niegodnych uwagi, obok takich synonimów jak: $\gamma \lambda i ́ \sigma \chi \rho \varsigma_{-}-$„brud-

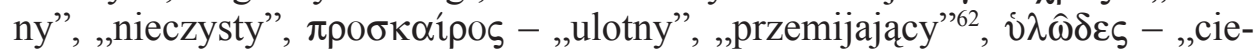
lesny”, „związany z materią" ${ }^{33}$ czy nawet $\kappa \tau \varepsilon v \hat{\omega} \delta \varepsilon \varsigma$ - „, bestialski”, „,niewłaściwy naturze ludzkiej” ${ }^{\prime 4}$. Podobnie w traktacie In inscriptiones Psalmorum

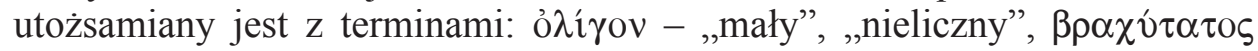
- „krótki”, „ograniczony”65. Grzegorz posługiwał się często hendiadycznym

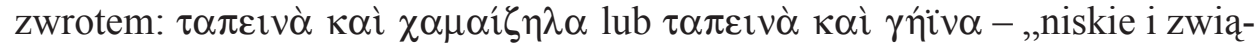
zane z ziemią, przylegające do ziemi, leżące na niej" ${ }^{\prime 6}$. Przymiotnik $\tau \alpha \pi \varepsilon \imath v o ́ \varsigma$ mógł w jego pismach oznaczać stan grzesznego upadku spowodowanego

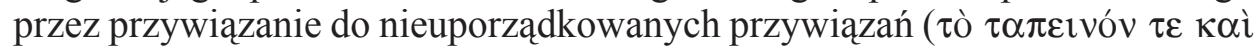

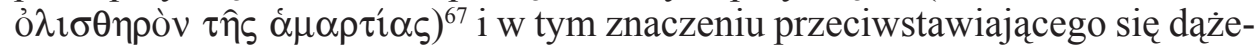
niu przez duszę do spraw wzniosłych, do których z natury jest ona powołana

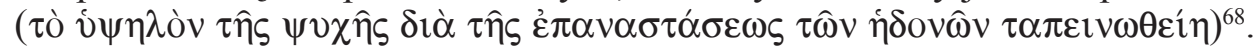

${ }^{58}$ Gregorius Nyssenus, De deitate Filii et Spiritui Sancti, PG 46, 564A.

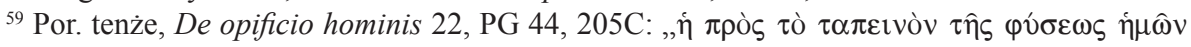

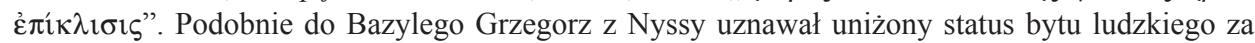
upamiętnienie ( $\delta$ ó $\mu \nu \eta \mu \alpha$ ) faktu, że został on stworzony przez Boga; zob. tenże, De creatione hominis sermo alter (spurium), ed. H. Hörner, GNO Supplementum, Leiden 1972, 62: „”E $\pi \lambda \alpha \sigma \varepsilon v$

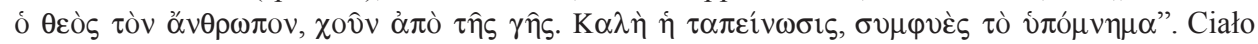
ludzkie, chociaż dobre samo w sobie, nazywa ciałem uniżenia ( $\tau$ ò $\sigma \hat{\omega} \mu \alpha \tau \hat{\eta} \varsigma \tau \alpha \pi \varepsilon \imath \omega ́ \sigma \varepsilon \omega \varsigma$ ); por. tenże, Contra Eunomium 1, 289, ed. W. Jaeger, GNO 1, Leiden 1960, 112; tenże, In Canticum canticorum 13, ed. H. Langerbeck, GNO 6, Leiden 1960, 380.

${ }^{60}$ Por. tenże, De opificio hominis 22, PG 44, 205C; tenże, Antirrheticus adversus Apollinarium, ed. F. Müller, GNO 3/1, Leiden 1958, 160; tenże, In inscriptiones Psalmorum 9, 47, ed. J. Reynard, SCh 466, Paris 2002, 354.

${ }^{61}$ Por. tenże, In illud: Tunc et ipse Filius, hom. 28, 8, PG 44, $1325 \mathrm{C}$.

${ }^{62}$ Por. tenże, De virginitate IV 3, 20-22, ed. M. Aubineau, SCh 119, Paris 1966, 310.

${ }^{63}$ Por. tamże IX 1, 30, SCh 119, 366.

${ }^{64}$ Por. tamże V 14-15, SCh 119, 336.

${ }^{65}$ Por. tenże, In inscriptiones PS. 8, 26, SCh 466, 248.

${ }^{66}$ Por. tenże, De virginitate XI 4, 13-15, SCh 119, 388; tenże, In Canticum canticorum 9, GNO 6, 262; tenże, Contra Eunomium 1, 242, GNO 1, 97; tenże, Antirrheticus adversus Apollinarium, GNO 3/1, 182; tenże, In Ecclesiasten 7, ed. P. Alexander, GNO 5, Leiden 1962, 403; tenże, In diem luminum (vulgo: In baptismum Christi oratio), ed. A. Spira, GNO 9, Leiden 1967, 229.

${ }^{67}$ Tenże, In inscriptiones Ps. 7, 15, SCh 466, 212; 7, 19, SCh 466, 220.

${ }^{68}$ Tenże, De virginitate V 2-4, SCh 119, 332-334; por. tenże, Vita S. Macrinae 17, 20-23, ed. P. Maraval, SCh 178, Paris 1971, 198. 


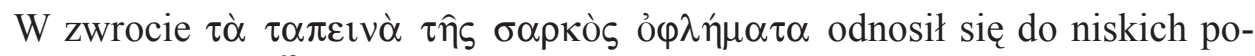
żądliwości ciała ${ }^{69}$. Był również synonimem pojęcia ó $\cos ^{\prime} \alpha$ - ,,bezprawie”, rozumianego jako przeciwstawienie się prawu Bożemu przez wypełnianie złych czynów ${ }^{70}$. We wszystkich wskazanych powyżej znaczeniach termin $\tau \alpha \pi \varepsilon i v \omega \sigma i \varsigma$ był przeciwstawiany przez Grzegorza pozytywnie rozumianej

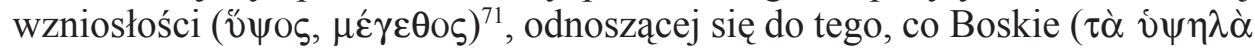

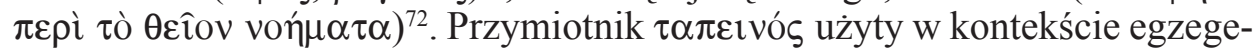

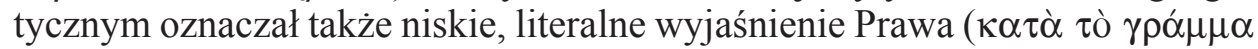

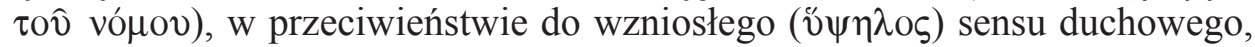
określanego terminem $\theta \varepsilon o \rho i ́ \alpha^{73}$.

Pozbawione konotacji negatywnych było u Grzegorza z Nyssy odniesienie słów z rdzeniem $\tau \alpha \pi \varepsilon \imath v$ - do Syna Bożego uniżającego się i przyjmujące-

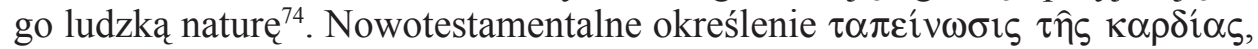
oznaczające pokorne uniżenie serca Chrystusa i Jego naśladowców, zachowało u Nysseńczyka swoje pozytywne znaczenie ${ }^{75}$. Według niego Jezus Chrystus połączył w sobie to, co wzniosłe i charakterystyczne dla sfery Boskiej ze stanem niskości właściwym człowiekowi jako stworzeniu żyjącemu w ciele będącym znakiem jego uniżenia ${ }^{76}$.

W zakończeniu traktatu De virginitate po raz pierwszy występuje rzeczow-

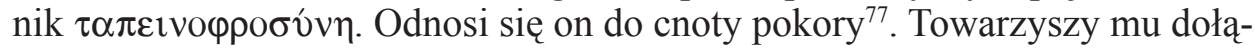
czone na zasadzie hendiadysu, przejęte z greckiej filozofii określenie $\mu \alpha \kappa \rho о-$ $\theta v \mu i ́ \alpha$ - ,wyrozumiała cierpliwość”, powracające zresztą dość często u Grzegorza na oznaczenie cnoty pokory ${ }^{78}$. W znaczeniu cnoty pokory, której najdoskonalszy wzór pozostawił Chrystus, występował termin $\tau \alpha \pi \varepsilon \imath$ vopooóv

${ }^{69}$ Por. tenże, De virginitate V 25, SCh 119, 336.

${ }^{70}$ Por. tenże, In inscriptiones Ps. 8, 22, SCh 466, 236.

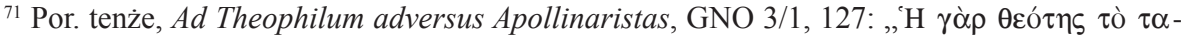

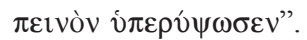

72 Tenże, In inscriptiones Ps. 1, 2, SCh 466, 164; por. tenże, Adversus Macedonianos de Spiritu Sancto, GNO 3/1, 99; tenże, De deitate adversus Evagrium (vulgo: In suam ordinationem), GNO 9, 335; tenże, Refutatio confessionis Eunomii 162, ed. W. Jaeger, GNO 2, Leiden 1960, 381.

${ }^{73}$ Por. tenże, De vita Moysis II 149, 3-7, ed. J. Daniélou, SCh 1bis, Paris 1968, 200.

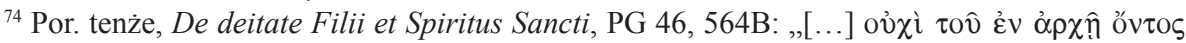

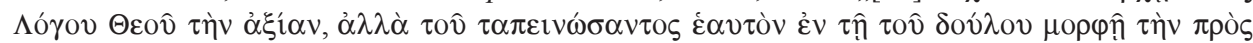

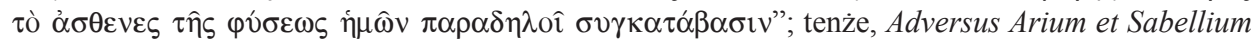
de Patre et Filio, GNO 3/1, 82; tenże, Testimonia adversus Iudaeos (spurium) 8, PG 46, $217 \mathrm{~A}$.

${ }^{75}$ Por. tenże, De mortuis non esse dolendum, GNO 9, 68.

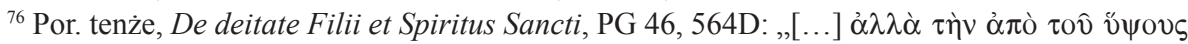

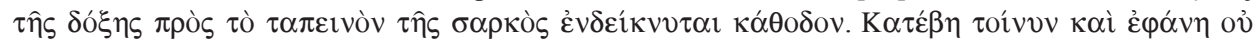

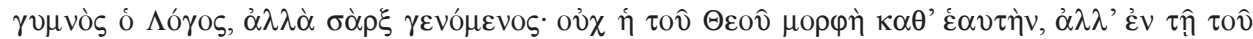

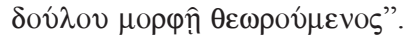

77 Por. tenże, De virginitate XXIII 3, 26-28, SCh 119, 536.

78 Por. tenże, De perfectione christiana ad Olympium monachum, PG 46, 272C-D; tenże, In Canticum canticorum 9, GNO 6, 272. 
także w innych dziełach Nysseńczyka ${ }^{79}$. Pojawiał się on nawet w brzmiącym

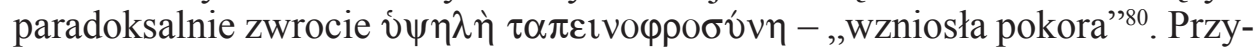

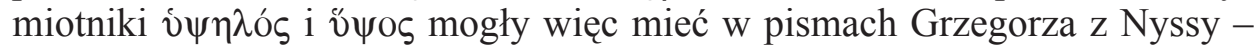
w zależności od kontekstu - dwojakie znaczenie: pysznego wywyższania się, przeciwstawiającego się pokorze, lub wzniosłości właściwej Bogu i ludziom zabiegającym o duchową doskonałość. W pierwszym znaczeniu odnosiły się one do przeciwieństwa cnoty pokory, określanej jako $\tau \alpha \pi \varepsilon \imath v o \varphi \rho o \sigma u ́ v \eta, ~ i ~ m o-$ gły nawet - paradoksalnie - towarzyszyć określeniu $\tau \alpha \pi \varepsilon i ́ v \omega \sigma \iota \varsigma$, wskazującemu na stan niskości związanej z przywiązaniem do spraw tego świata. W drugim znaczeniu zachodziła sytuacja odwrotna: przymiotniki te charak-

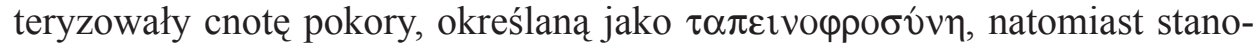
wiły przeciwieństwo terminu $\tau \alpha \pi \varepsilon^{i} v \omega \sigma \iota \varsigma$, użytego w znaczeniu grzesznego uniżenia.

Wadę pychy określał Grzegorz z Nyssy przede wszystkim rzeczownikiem i $\pi \varepsilon \rho \eta \varphi \alpha v^{\prime} \alpha$ - „pogardliwa wyniosłość” "81, rzadziej rzeczownikami $\chi \alpha v v o ́ \tau \eta \varsigma$

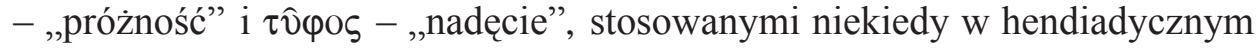

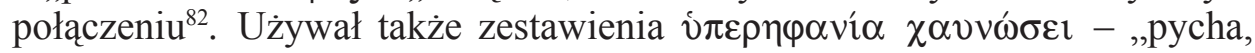
która prowadzi do wywyższenia”, „zarozumiałość, która będzie się panoszyć", wzmagającego negatywny wydźwięk tej wady ${ }^{83}$. Utrzymywał się więc pod tym względem w tradycyjnym nurcie, natomiast odróżniało go od Bazylego, a zwłaszcza od Grzegorza z Nazjanzu, unikanie najpopularniejszego w starożytności terminu używanego na określenie pychy - úßpıs. Na określenie ogólnie rozumianej wzniosłości, zarówno w pozytywnym, jak i negatywnym znaczeniu, stosował Nysseńczyk - jak wspomniano wyżej - przymiotniki

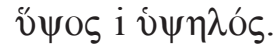

4. W pismach Jana Chryzostoma. W zachowanych pismach Jan Chry-

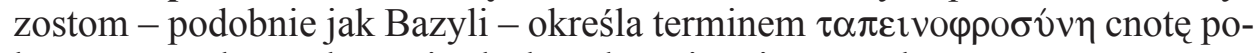
kory, prowadzącą do życia doskonałego i świętego, ukazaną we wzorcowy sposób przez Chrystusa ${ }^{84}$. Uniżenie związane w sposób konieczny ze statusem ludzkiej natury stworzonej wyraża natomiast w formie hendiadysu z użyciem

${ }^{79}$ Por. tenże, Adversus Arium et Sabellium de Patre et Filio, GNO 3/1, 82; tenże, Oratio funebris in Meletium episcopum, GNO 9, 449; tenże, Vita S. Macrinae 11, 8, SCh 178, 176; tenże, In sanctum Ephraim, PG 46, 837B.

${ }^{80}$ Tenże, Oratio funebris in Flacillam imperatricem, GNO 9, 480 i 488.

${ }^{81}$ Por. tenże, De vita Moysis II 280, 5-6, SCh 1bis, 296; tenże, Oratio catechetica magna, GNO $3 / 4,73$.

${ }^{82}$ Por. tenże, De virginitate IV 3, 20, SCh 119, 310; tenże, De mortuis non esse dolendum, GNO

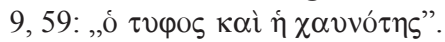

${ }^{83}$ Por. tenże, Oratio consolatoria in Pulcheriam, GNO 9, 469.

${ }^{84}$ Por. Joannes Chrysostomus, Epistulae ad Olympiadem VIII 5, 34-36, ed. A.M. Malingrey,

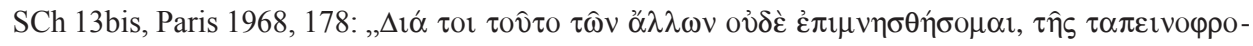

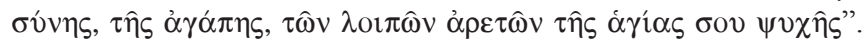


przymiotnika $\tau \alpha \pi \varepsilon \imath$ ós, zestawiając jako nierozłączne cechy to, co niskie

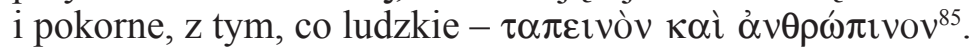

Przymiotnik $\tau \alpha \pi \varepsilon \imath$ ós i rzeczownik $\tau \alpha \pi \varepsilon i ́ v \omega \sigma \imath \varsigma-$ zgodnie z praktyką Ojców Kapadockich - mają u Chryzostoma znaczenie szersze niż $\tau \alpha \pi \varepsilon \imath v o-$

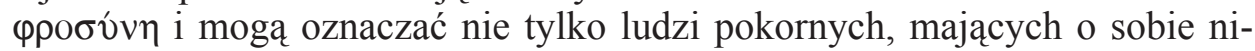
skie mniemanie, ale także zajmujących gorszą pozycję społeczną - niskiego pochodzenia i wzgardzonych ${ }^{86}$. O polisemantyczności terminu $\tau \alpha \pi \varepsilon i v \omega \sigma ı \varsigma$ świadczy klasyfikacja jego znaczeń zawarta w Komentarzu do Psalmów. Może on oznaczać cnotę pokory ( $\tau \alpha \pi \varepsilon i ́ v \omega \sigma ı \varsigma ~ \alpha ُ \rho \varepsilon \tau \hat{\jmath} \varsigma$ ), ale także: nędzne położenie związane z nieszczęściami spotykającymi człowieka ( $\alpha \pi o ̀ ~ \sigma v \mu \varphi o \rho \hat{v} v)$; upodlenie wywołane popełnionymi grzechami ( $\alpha \pi$ ò $\alpha \mu \alpha \rho \tau \eta \mu \alpha ́ \alpha \omega \nu)$; niskość, którą - paradoksalnie - powoduje pycha ( $\dot{\varepsilon} \xi \alpha \dot{\alpha} \pi$ ovoí $\alpha \varsigma)$; stan przywiązania do tego, co jest na ziemi, czyli nisko, wywołany przez nienasyconą pożądliwość $(\alpha \dot{\alpha} \pi \text { ò } \tau \hat{\eta} \varsigma \alpha \dot{\alpha} \pi \lambda \eta \sigma \tau i \alpha \varsigma)^{87}$.

Złotousty kaznodzieja, charakteryzując pokorę i przeciwstawiając ją pysze, korzysta z całego arsenału starożytnych pojęć filozoficznych, przynajmniej częściowo odpowiadających zakresem temu, co chrześcijaństwo nazywa pokorą i pychą. Aby właściwie zrozumieć myśl Chryzostoma należy pamiętać, że moralność antyczna pielęgnowała ideał wielkości duszy, zwany

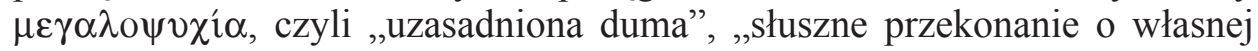
wielkości" ${ }^{88}$. Arystoteles przeciwstawiał tę postawę pysze i określał „ozdobą

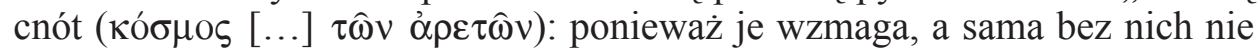
może istnieć" 99 . Ideał ten polegał na uznaniu siebie za zdolnego do wielkich rzeczy, ponieważ takim się rzeczywiście jest, czyli na posiadaniu słusznej opinii o sobie samym i poczuciu własnej wartości, co niekiedy mogło jednak prowadzić do gardzenia słabszymi od siebie i nie akcentowało należycie pomocy ze strony Boga, jaką człowiek otrzymuje do wypełniania dobrych czynów, tak bardzo podkreślanej potem w chrześcijańskiej koncepcji pokory ${ }^{90}$.

${ }^{85}$ Tenże, De consubstantiali (Contra Anomoeos homilia VII) 4, PG 48, 761-762; por. tenże, De sancto Babyla contra Iulianum et gentiles 16, 4-5, PG 50, 557-558.

${ }^{86}$ Por. tenże, In Epistulam ad Romanos hom. 22, 2, PG 60, 611, tłum. T. Sinko: Św. Jan Chryzostom, Homilie na list św. Pawła do Rzymian, I/2, Kraków 1998, 353.

${ }^{87}$ Por. tenże, Expositiones in Ps. 142, 3, PG 55, 450.

${ }^{88}$ Por. R.A. Gauthier, Magnanimité. L'idéal de la grandeur dans la philosophie païenne et dans la théologie chrétienne, Paris 1951, 250.

${ }^{89}$ Aristoteles, Ethica nicomachea IV 7, 1124a 1-3, ed. Susemihl - Apelt, s. 80, tłum. D. Gromska: Arystoteles, Etyka nikomachejska, w: Arystoteles, Dzieła wszystkie, VI, Warszawa 2001, 155 (tłum. poprawione).

${ }^{90}$ Por. tamże IV 7, 1124a-1125b, ed. Susemihl - Apelt, s. 80-84, tłum. Gromska, s. 155-158: „Człowiek [...], który jest słusznie dumny ( $\mu \varepsilon \gamma \alpha \lambda$ ó $\psi v \chi 0 \varsigma)$, jest nim przede wszystkim ze względu

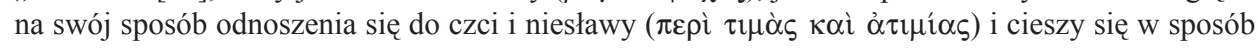
umiarkowany ( $\mu \varepsilon \tau \rho i ́ \omega \varsigma)$ zaszczytami wielkimi i pochodzącymi od ludzi szlachetnych [...], lekceważyć natomiast będzie zaszczyty pochodzące od byle kogo i z powodów czynów bez znaczenia [...]. Będzie pełen umiarkowania i nie będzie człowiek taki ani zbytnio cieszył się powodzeniem, 
W Panegirykach na cześć św. Pawła Jan Chryzostom zestawia w odniesieniu do osoby Apostoła narodów dwa pozornie nie związane z sobą poję-

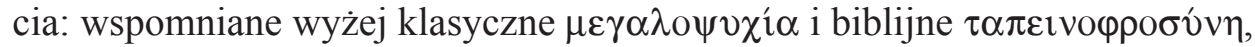
stwierdzając, że Paweł przemawiał z pokora, ale równocześnie z mocą, świadomy wielkiego znaczenia orędzia pochodzącego od Boga ${ }^{91}$. Termin $\mu \varepsilon \gamma \alpha-$ $\lambda$ o $\psi v \chi i \alpha$ ma tu jednak niewiele wspólnego z pierwotnym Arystotelesowskim znaczeniem poczucia własnej samowystarczalności i wielkości. Wskazuje on raczej na godność człowieka, wynikającą z jego pokornego podporządkowania się Bogu. Cechy typowej Arystotelesowskiej $\mu \varepsilon \gamma \alpha \lambda$ o $\psi v \chi i \alpha$ przybiera natomiast u Jana Chryzostoma pojęcie pychy, określane również tym terminem ${ }^{92}$. W homiliach In illud: Vidi Dominum Złotousty określa pychę jako podstawową wadę i zaprzeczenie pokory przy pomocy terminów $\alpha \lambda \alpha \alpha \zeta o v \varepsilon i ́ \alpha$ i i $\pi \varepsilon \rho \eta \varphi \alpha v^{\prime} \alpha^{93}$, zaczerpniętych z Charakterów Teofrasta i będących tam nazwami odmian próżnej pychy przeciwstawiającej się ,,słusznej dumie” $(\mu \varepsilon \gamma \alpha-$ $\lambda o \psi v \chi i \alpha)^{94}$. W Homiliach na list św. Pawła do Rzymian używa pojęcia $\mu \varepsilon-$

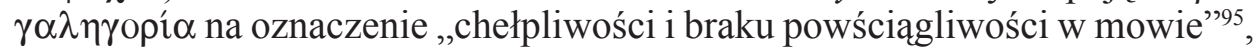

ani zbytnio martwił niepowodzeniem. [...] Skłonny jest do świadczenia dobrodziejstw, lecz kiedy ich doznaje, wstydzi się (pierwsze bowiem jest rzeczą tego, kto ma nad kimś przewagę, drugie rzeczą tego, nad którym się ją ma). [...] Ludzie słusznie dumni zdają się też pamiętać o tych, którym wyświadczyli jakąś przysługę, zapominać zaś o tych, od których doznali przysług; bo ktoś, komu wyświadczono przysługę, jest w gorszym położeniu od tego, kto ją wyświadczył, człowiek zaś słusznie dumny pragnie mieć przewagę. [...] Jest dalej właściwością ludzi słusznie dumnych nie dążyć do tego, z czym łączą się zazwyczaj zaszczyty lub w czym przodują inni, lecz raczej zachowywać się pod tym względem biernie i ociagać się, chyba że idzie o wielkie zaszczyty lub wielkie dzieło, i przedsiębrać niewiele, ale za to rzeczy wielkich i godnych rozgłosu. Musi też człowiek słusznie dumny nienawidzić otwarcie i otwarcie kochać; gdyż tylko ten, kto się boi, ukrywa [swe uczucia]. I musi dbać więcej o prawdę niż o pozory i mówić oraz postępować otwarcie, jako że pogarda czyni mowę jego śmiałą. [...] Dalszą cechą człowieka słusznie dumnego jest niemożność stosowania się w życiu do kogoś innego, chyba do przyjaciela; takie bowiem stosowanie się ma w sobie coś niewolniczego [...]".

${ }^{91}$ Por. Joannes Chrysostomus, De laudibus sancti Pauli apostoli hom. 5, 8, ed. A. Piédagnel,

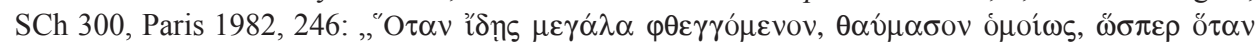

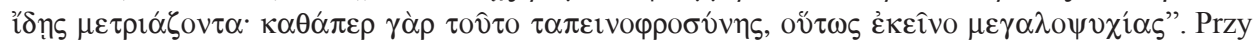
okazji należy wspomnieć, że termin $\mu \varepsilon \gamma \alpha \lambda \circ \psi v \chi i \propto \alpha$ miał u Jana Chryzostoma także znaczenie rozpowszechnione później w chrześcijaństwie, chociaż wywodzące się także od Arystotelesa: „życzliwość”, „hojność”, otwartość serca”, przeciwstawiające się skapstwu, zob. tenże, In Epistulam ad Romanos hom. 21, 2, PG 60, 603-604, thum. Sinko, I/2, s. 342; tenże, In Acta Apostolorum hom. 48, 3, PG 60, 336.

${ }^{92}$ Por. tenże, Expositiones in Ps. 142, 3, PG 55, 450-451.

${ }^{93}$ Tenże, In illud: Vidi Dominum, hom. 4, 3-4, PG 56, 124-125.

${ }^{94}$ Por. Theophrastus, Characteres 24, ed. Edmonds, s. 102-104.

${ }^{95}$ Por. tenże, In epistulam ad Romanos hom. 7, 1, PG 60, 442, thum. T. Sinko: Św. Jan Chryzostom, Homilie na list św. Pawła do Rzymian, I/1, Kraków 1995, 105. 
natomiast w Homiliach na Ewangelię według św. Mateusza mówi o ỏđóvor $\alpha$, czyli „zarozumiałości”, związanej z pychą i decydującej o jej szkodliwości ${ }^{96}$.

Z przedstawionej analizy porównawczej terminów odnoszących się do cnoty pokory i wady pychy w pismach Ojców Kapadockich i Jana Chryzostoma wynika, że stosowali oni zarówno terminologię biblijną jak i starożytne słownictwo greckie, zmieniając $\mathrm{w}$ duchu chrześcijańskim jego pierwotną semantykę. Pierwszorzędną rolę odgrywały terminy występujące w Biblii, na czele $z$ określeniem cnoty pokory - $\tau \alpha \pi \varepsilon \imath$ vo i rzeczownik $\tau \alpha \pi \varepsilon i ́ v \omega \sigma ı \varsigma$ miały zasadniczo szersze pole semantyczne niż $\tau \alpha$ $\pi \varepsilon \imath$ เ stan uniżenia człowieka jako bytu stworzonego lub uniżenie zawinione przez grzech, a także wszelką niskość w świecie ducha lub materii. Nadawanie przymiotnikowi $\tau \alpha \pi \varepsilon \imath$ vós pozytywnych pod względem moralnym aspektów znaczeniowych było cechą charakterystyczną literatury wczesnochrześcijańskiej, odróżniająca ją od większości wcześniejszych tekstów greckich, w których miał on zasadniczo wydźwięk negatywny. Zespół terminów na określenie pychy pozostawał natomiast niezmienny od czasów starożytnej filozofii i literatury greckiej, która tej wadzie poświęciła nie mniej miejsca niż później chrześcijaństwo.

Obok akcentowania chrześcijańskiej specyfiki postawy pokory oraz podkreślania jej religijnego i duchowego wymiaru, teologowie greccy IV wieku usiłowali zdefiniować ją językiem filozoficznym jako cnotę etyczną. W tym celu musieli posłużyć się niezastąpionymi zasobami pojęciowymi filozofii starożytnej oraz słownictwem utrwalonym w klasycznej grece (szczególnie

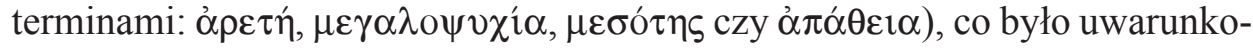
wane zasadą akomodacji misyjnej.

\section{TERMINOLOGY OF HUMILITY AND PRIDE IN THE WRITINGS OF THE GREEK FATHERS OF THE CHURCH OF THE $4{ }^{\mathrm{TH}}$ CENTURY}

\section{(Summary)}

The aim of the presented paper is to analize the terminology describing humility and pride that appears in the writings of the Greek Fathers of the Church of the $4^{\text {th }}$ century (Basil the Great, Gregory of Nazianzus, Gregory of Nyssa, John Chrysostom). To describe a humility they used the traditional terms $-\tau \alpha \pi \varepsilon i v \omega \sigma ı \varsigma$ or $\tau \alpha \pi \varepsilon \imath v o ́ \tau \eta \varsigma$ - that derived from ancient philosophy and were also well known

${ }^{96}$ Tenże, In Matthaeum hom. 65, 6, PG 58, 625, thum. A. Baron - J. Krystyniacki: Św. Jan Chryzostom, Homilie na Ewangelię wedlug św. Mateusza. Część druga, Kraków 2001, 288. 


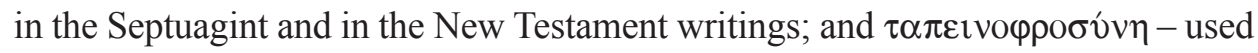
in the letters by Saint Paul and Saint Peter. The ancient Greek thought didn't know a virtue of humility, so the philosophers didn't use the last of these terms. However, the first two were used in the ancient Greek literature, but usually in a pejorative sense and meant „,smallness”, „weakness”, ,misery”. In the works of Greek Fathers of the Church the adjective $\tau \alpha \pi \varepsilon$ vó $\varsigma$ and the substantive $\tau \alpha \pi \varepsilon i v \omega \sigma ı \varsigma$ had

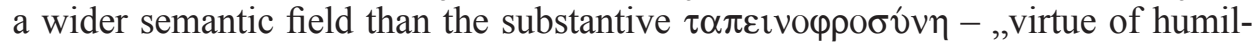
ity". They could have meant the virtue of humility, as well as a natural state of abasement of man as a created being; or a humiliation caused by the sin, and even all lowliness in the world of spirit and matter. The terms associated with the pride ( the Church, remained unchanged since the time of ancient Greek philosophy and literature, which devoted to this fault not less space than later Christianity. 